\title{
Research on the Construction of Shared Incubation Base from the Perspective of Innovation
}

\author{
Lingli Chu ${ }^{1,}$ a Baoyan $\mathbf{L u}^{2,}$ b \\ ${ }^{1}$ Baicheng Normal College, School of Economic Management, Baicheng, Jilin \\ ${ }^{2}$ Baicheng Normal College, School of Civil Engineering, Baicheng, Jilin \\ a1025166554@qq.com; bjdxlubaoyan@126.com
}

Keywords: Sharing Type; Innovation and Entrepreneurship; Practical Training Base; Construction

\begin{abstract}
Based on the analysis of the present situation of the construction of the west of Jilin Province College of business incubators, find out the objective factors affecting and restricting the construction of College Students' entrepreneurial base, proposed the university to create a shared type business incubator mode, based on shared business incubator functions, puts forward the corresponding measures of incubator construction and operation, also provide directions and suggestions for the construction of College Students' entrepreneurial base.
\end{abstract}

\section{Introduction}

At present, the state has issued a series of policies to support innovation and entrepreneurship, and it has set off a wave of "mass entrepreneurship and innovation" in the whole society. It has provided good opportunities and broad stage for college students' innovation and entrepreneurship. According to statistics, college students accounted for about $89.8 \%$, considered to start a business, there are $18.2 \%$ college students have a strong entrepreneurial intention, from the entrepreneurial will reflects the current situation of College Students' entrepreneurial development. In the face of the rise of College Students' entrepreneurial enthusiasm, the students are able to provide a platform for innovation and entrepreneurship, entrepreneurial power can become the most solid and most heavy positions, of higher education is an urgent problem to be solved.

With the continuous advance of teaching, sharing of business incubators in the form of open for sharing, school enterprise integration, resources, construction goal of innovation and entrepreneurship training base of the concept, the use of the Internet thinking, combined with local economic development needs, complete the selection and training, shock before the task, the implementation of innovative development strategy and the foundation for national talent.

\section{The Function of Shared Incubation Base}

Students start sharing type incubator incubator, in accordance with the innovation project of business incubators, entrepreneurship design, shared business incubators to reflect today's advocacy of "investment promotion", "creating hatch type" and "type," media training extension "and" professional services "the incubator of new features. The transformation of sharing platform construction incubator to open the whole of society.

\section{A. Incubation of Entrepreneurial Talents}

The development of an enterprise, the success of the establishment, talent is the decisive factor. Therefore, under the situation of fierce market competition, enterprises to cultivate high-quality technical staff is an important factor in the development of enterprises, the integration of talent training base, consulting, project, staff resources, training a group of both science and technology knowledge and talents management, to promote local industrial structure optimization and upgrading quality and efficiency of economic supply talent guarantee.The essence of innovation and entrepreneurship education is a kind of cultivating students' innovative spirit, entrepreneurship, entrepreneurial skills education, the methods and ways of training the students how to adapt to the 
social life, self employment, self occupation. Entrepreneurial activities is to create entrepreneurial personality, enhance the comprehensive qualities of entrepreneurs, improve the innovation ability as the core process of incubator is realized an important complement and extension of innovative talent training in University, also reduce the operating costs of the enterprise founded and talent training cost, shorten the business start-up time, realize the enterprise resources sharing and win-win.

\section{B. Incubation Project}

Guide students to bring innovation projects to the base, and cultivate the basic accomplishment, basic skills and basic abilities of the students. To achieve the effective combination of practice teaching and students' science and technology innovation base in Jilin Province, the college students' innovation and entrepreneurship training program, a youth competition, innovation and entrepreneurship comprehensive practice project of excellent works, enterprises registered in the temporary incubator, to carry out research work, after a period of incubation, the conditions can be officially registered. We should make full use of and bring into full play the discipline and talent resources of universities and colleges, and rely on College Students' scientific and technological activities and participate in innovation and entrepreneurship competition projects, and introduce new knowledge, new technologies and inventions. Universities in Britain pay great attention to training students' practical ability and innovative ability. The courses offered by engineering majors in British universities include 30\%-60\%, experiment, engineering and curriculum design. The purpose is to train students' hands-on practice ability, [3]. Through practical activities to promote the transformation of scientific and technological achievements projects in Colleges and universities, accelerate the growth of regional small and micro enterprises, form a new engine of local economic growth, and feed back the development of innovation and entrepreneurship education in Colleges and universities.

\section{Construction Model of Shared Incubation Base}

The construction of shared business incubators to regional economic development as an opportunity to combine pillar industry and talent development needs, grasp the base construction goals, vision and mission to undertake relations, innovation project task driven, explore new modes of the construction of business incubators.

\section{A. The Model of Alliance and Base Organization}

In the process of entrepreneurship, college students are also faced with difficulties such as lack of funds, project selection, lack of tutors and poor policies. Alliance is initiated by the Communist Youth League Committee or, combined with regional colleges and universities financial institutions, chambers of Commerce and other relevant agencies jointly set up the service innovation and entrepreneurship college public welfare organization, and entrepreneurship loan Guarantee Corporation and enterprise cooperation. The alliance insists on the principle of youth subject and the principle of serving the local economy, with the university students as the key service object and the organizations and individuals with the intention of entrepreneurship to join. Alliance to take online and offline form of integration, innovation and entrepreneurship policy advocacy, skills training. Create a student internship base, help enter the workplace, organize road show activities, and contact the business mentor and project. Carry out business loan application services, docking investment institutions. To realize the combination of alliance and University mentor group, to achieve the organic unity, give full play to the regional resource gathering and sharing of information resources, financing effective docking, to provide financial resources, material resources and intellectual support for entrepreneurial students, students realize the coordinated development of venture capital and entrepreneurial innovation. To build a base in the organization, technology research and development to achieve seamless convergence of all sectors of society, coordinating with the local government and promoting the cooperation between the industry, to provide a good ecological environment for college students. 


\section{B. The Model of Platform and Teaching Workshop}

In the school set up advanced technology, well-equipped and realistic environment "Teaching Workshop", the enterprises moved into the campus, to provide students with a good entrepreneurial environment. Through platform and teaching workshop mode, students' core competence of entrepreneurship should be cultivated, and entrepreneurial theory platform, entrepreneurial training platform and incubator platform will be set up to simulate the operation of enterprises and train students' reform and innovation. The era of the new industrial revolution is an era full of innovation, and requires a large number of distinctive innovative talents to support. Rich personality development is the source of innovative spirit and entrepreneurial ability. In order to cultivate students' creative thinking and stimulate their potential for innovation and entrepreneurship, we must first update the traditional educational concept. In order to meet the needs of individual talent, "teaching factory" design professional positions corresponding to the background in the showroom, chemical raw materials, metal materials, building materials, and other commodities, training entrepreneurial ability, to cultivate students' innovation ability. Teachers rely on scientific and technological projects to establish projects, research institutes, studios and other internal entrepreneurship. Entrepreneurial base is an open base for entrepreneurship, not only for college students, but also for alumni, society oriented, teacher oriented. Schools have issued a number of regulations to support teachers to encourage the incubation project, establish enterprises, support teachers and students to set up enterprises. Such as foreign language institute teachers can lead students to set up a translation type companies, Architectural Engineering Institute, you can start the construction cost company. According to the German dual system is a kind of school enterprise cooperation in the school system, by the enterprise and the school together to take the important task of cultivating innovative talents, the school in accordance with the specific requirements of enterprises for talents to organize teaching and training. Realized the teacher, the student, the specialized benign development.

\section{C.The Model of Entrepreneurship and Incubation Workshop}

The teaching workshop is a incubation incubator for business incubation, which mainly undertakes the innovation and entrepreneurship competition of the base, screens creative projects, and delivers excellent entrepreneurial teams to the incubation workshops, so as to complete the docking of the projects. This model of campus workshop has realized the integration of teachers and engineers, realized the integration of students and employees, and realized the one-stop docking between youth entrepreneurship projects and policies, funds and resources. Form a virtuous cycle of base input and enterprise return, and ensure the function of the entrepreneurial base. Business incubator management workshop to achieve the cooperation of colleges and universities base, laboratory experiment, joint workshops, cooperation with financial institutions, to help entrepreneurs to finance investment to stimulate entrepreneurship, entrepreneurial base with the migration potential of entrepreneurs once have good ideas, good projects, guidance and financing service base to give professional.

\section{4 . Shared Venture Incubator Base Operation Measures}

Entrepreneurial base set management and public welfare in one, through expansion and reconstruction, improve the management system and service function, enhance the ability to absorb and become the incubator service platform to promote effective national entrepreneurship and the birth of medium and small enterprises.

\section{A. Zero Threshold Access for Incubation Enterprises}

Business incubators can help entrepreneurs to the shore, on the road to success for a guest house rent, the implementation of free services such as water and electricity, heating, lighten the pressure of the entrepreneurs, the creative good projects innovation incubation works, through the audit, access to production orders, base try our best, under the temptation of zero threshold to turn ideas into reality. After entering the enterprise, we create a good atmosphere for entrepreneurs to encourage innovation and failure, and encourage and support entrepreneurs to make great efforts for 
better creative projects. The function of the base is to refine the service, motivate employees to improve their productivity, and make targeted start-up capital, and use the market mechanism to promote the development of start-ups. Effective play to the role of the various types of capital, further exploration to improve the operating mode of incubators helping entrepreneurs hard wings, in the whole chain during the case, and the enterprise stand out from the geek.

\section{B. Zero Pressure Operation of Incubators}

In business incubation works, start a business success rate is low, the base allows entrepreneurs to trial and error, the return request is not urgent, has a high tolerance of losses, tolerant atmosphere lightened the burden and pressure, entrepreneurs inspired entrepreneurial motivation. On the one hand, the enterprise in the early stage of the enterprise will be able to land, take root and sprout, cultivate and support the project, and carry out the whole process management. , on the other hand, the implementation of social management mechanism, students set up company procedures complete socialization, clear responsibility, by competitive recruiting suitable employees, according to start a business organization procedure to manage the staff, build a batch of high market potential, strong innovation ability of small micro enterprise, do your enterprise larger at an early date.

\section{C.Incubate New Ecological Chains}

Entrepreneurship incubation workshop is an incubator platform integrating entrepreneurship and investment, setting up maker space, entrepreneurial employment training and enterprise hatchery. Gen passenger space is also new ideas into reality, live, real works, it is to cultivate innovative entrepreneurial talent, selected a number of business elite, can be directly into the enterprise incubation, corporate finance, enterprise promotion link. Base, make full use of national, provincial, city, area of support college students pioneering, youth talents, science and technology innovation, small micro enterprise development of preferential policies, strive to build perfect orderly innovation service system, provide software support for industry hatching breeding. In order to improve the industry nurturing ability and entrepreneurial base project incubation, joint industrial and commercial affairs agency, financial accounting, tax affairs agent, patent agency, legal services, business management consulting services and mentors, financing of enterprise business salon, lectures, business management training and other activities. Introducing various is advantageous to the policy of entrepreneurship and innovation business incubators, match the regional economy, industry development goals, to attract more high-tech talent and technical service projects to concentrate in business incubators.

\section{D.Expand New Financing Channels}

Building integration of comprehensive financial service platform of science and technology, to better provide financing guarantee service for small and medium-sized enterprise innovation and entrepreneurship, lead Banks, guarantee agencies to provide financing services to small and medium-sized enterprise innovation and entrepreneurship, set up angel funding for college students provide direct financing service business, entrepreneurs can enjoy free of risk assessment, policy and legal training, loan guarantees, tax breaks and other free of charge, at the same time base to set up a venture fund, interest-free loans, seed funding support. We will increase investment in venture capital, and provide business tax, legal consultation, policy guidance, contract signing, assistance, guidance and one-stop service for the establishment of enterprises.

\section{5 . Conclusion}

In the mode of the organization of the league, the mode of platform teaching, and the model of innovation incubation, the incubation of enterprises, the incubation of talents and the incubation of the project are realized. Into a set of business, teaching, scientific research in the integration of Shared business incubators, realize the integration education, coordinating education, to promote innovation in colleges and universities entrepreneurship education to professional longitudinal deepening, the practical production and education, the education of fine development, improve students' innovative entrepreneurial ability. 


\section{Acknowledgments}

This work was supported by the "Construction and Practice of Entrepreneurship Incubation Base for College Students in Western Universities in Jilin Province" (Jilin Provincial Department of Education, No. 29, 2016) in part. The author would also like to thank the reviewers for their corrections and helpful suggestion.

This work was supported by the Research on "Research on the Operation of Entrepreneurial Employment Shared Training Base for College Students in Jilin Province" (Jilin Provincial Department of Education, No. 385, 2015)in part also. The author would also like to thank the reviewers for their corrections and helpful suggestion.

\section{References}

[1] He Liguo, Shen Lijian. The Positioning and the Act of Collaborative Innovation of Higher Vocational Colleges[J]. Research of Heilongjiang High Education, 2013 (12); [2]Tang Jiafang. Innovation Entrepreneurship Education and College Students' Self-sustainable Development[J]. Education and Career,2008(10);

[3]Xia Xiaohua. Experience and Revelation of Education Innovation and Entrepreneurship in Foreign Universities[J]. Journal of Jixi University,2014(06);

[4]Wan Youxiang,Kong Xinzhou.Exploration of the Construction Mode of College Students' Entrepreneurial Base[J].Chinese University Science and Technology

,2013(01);

[5]Zhou Xiaoding, Huang Qun. The Collaborative Innovation Model of German Universities and Enterprises and Their Reference[J].German Study,2013(02). 